\title{
ANALISIS NILAI TAMBAH PENGASAPAN IKAN TAWES DI KABUPATEN LAMONGAN
}

\section{VALUE ADDED ANALYSIS OF SMOKING TAWES IN LAMONGAN DISTRICT}

\author{
Wachidatus Sa'adah \\ Fakultas Perikanan Universitas Islam Lamongan \\ Email: wachidaafandi@gmail.com \\ (Diterima 25-06-2021; Disetujui 16-07-2021)
}

\begin{abstract}
ABSTRAK
Ikan tawes merupakan ikan air tawar yang mudah dipelihara di kolam maupun tambak di wilayah Lamongan dan ketersediaannya melimpah di pasar. Namun jika dijual dalam kondisi segar harganya paling murah diantara jenis ikan lainnya. Oleh karena itu, dilakukan upaya peningkatan nilai tambah ikan tawes dengan cara pengawetan dengan metode pengasapan. Tujuan dari penelitian ini adalah untuk mengetahui nilai tambah dari pengasapan ikan tawes di Kabupaten Lamongan. Metode yang digunakan dalam penelitian ini adalah metode kuantitatif, dan pengambilan sampelnya dilakukan secara purposive sample, dengan perhitungan analisis nilai tambah metode Hayami. Hasil akhir penelitian menunjukkan bahwasanya nilai tambah yang diperoleh adalah Rp6.858/kg dengan rasio nilai tambahnya adalah $24,5 \%$.
\end{abstract}

Kata kunci : Nilai Tambah, Ikan Tawes, Ikan Asap

\section{ABSTRACT}

Tawes fish is a freshwater fish that is easy to maintain in ponds and ponds in the Lamongan area and its availability is abundant in the market. However, if it is sold fresh, the price is the cheapest among other types of fish. Therefore, efforts were made to increase the added value of Tawes fish by preserving it using the smoking method. The purpose of this study was to determine the added value of smoking Tawes fish in Lamongan Regency. The method used in this study is a quantitative method, and the sampling is done by purposive sampling, with the calculation of value added analysis using the Hayami method. The final result of the research shows that the added value obtained is Rp6.858/kg with the ratio of added value is $24,5 \%$

Keywords : Added Value, Tawes Fish, Smoked Fish

\section{PENDAHULUAN}

Ikan sebagai bahan makanan yang mengandung protein tinggi dan juga mengandung asam amino esensial yang dibutuhkan oleh tubuh, disamping itu nilai biologisnya mencapai $90 \%$, dengan jaringan pengikat sedikit sehingga mudah dicerna. Yang terpenting lagi bahwa harga ikan lebih murah dibandingkan dengan sumber protein lain. Di lain hal ikan merupakan bahan pangan yang mudah rusak (membusuk), hanya dalam waktu sekitar 8 jam sejak ikan ditangkap dan didaratkan sudah akan timbul proses perubahan yang mengarah pada kerusakan. Karena itu agar ikan dan hasil perikanan lainnya dapat dimanfaatkan 
semaksimal mungkin, perlu dijaga kondisinya (Rabiatul, 2014).

Ketersediaan ikan segar yang melimpah tidak akan habis sekaligus, apabila dibiarkan akan mengakibatkan mundurnya mutu dan turunnya harga produk. Oleh karena itu, perlu dikembangkan berbagai cara pengawetan dan pengolahan yang cepat serta cermat agar sebagian besar produk yang diproduksi dapat dimanfaatkan (Rahardi, 2004).

Produk pengawetan dan olahan tidak kalah dengan produk segar, karena mampu memberikan nilai tambah yang diperoleh dari hasil akhir produk, misalnya pada aroma, rasa, bentuk dan tekstur yang bisa memenuhi selera konsumen. Metode pengawetan dan pengolahan mempunyai persamaan yaitu bertujuan untuk mempertinggi daya tahan dan daya simpan ikan agar kualitas ikan dapat dipertahankan tetap dalam kondisi baik (Eddy, dkk, 2009).

Metode yang bisa diterapkan untuk memberikan nilai tambah salah satunya adalah metode pengawetan dengan pengasapan yakni bentuk pengawetan yang dilakukan melalui beberapa tahapan yaitu penggaraman, pengeringan, pemanasan, dan terakhir pengasapan.
Menurut Wibowo (2002), dengan pengasapan bisa memberikan daya awet karena:

(1) panas dari pembakaran dapat menghambat mikroorganisme.

(2) asap mengandung komponen antimikroba (bakterisida/ bakteristatik).

(3) mengandung antioksidan sehingga dapat terhindar dari ketengikan.

(4) sebagian asap membentuk kulit tipis sehingga dapat terhindar dari kontaminasi ulang.

Adapun komoditi ikan yang akan digunakan dalam proses pengawetan adalah ikan tawes, alasan kenapa memilih ikan tersebut karena merupakan ikan air tawar yang mudah dipelihara di kolam maupun tambak di wilayah Lamongan, dan ketersediaannya melimpah di pasar. Permasalahannya jika dijual dalam kondisi segar harganya paling murah diantara jenis ikan lainnya. Oleh karena itu, dilakukan upaya peningkatan nilai tambah ikan tawes dengan cara pengawetan dengan metode pengasapan.

Dari latar belakang dan permasalahan tersebut, maka tujuan dari penelitian ini adalah untuk mengetahui nilai tambah dari pengasapan ikan tawes di Kabupaten Lamongan. 


\section{METODE PENELITIAN}

Penelitian ini dilaksanakan di Kecamatan Sukorejo Kabupaten Lamongan. Pemilihan lokasi berdasarkan metode puporsive sample karena didasarkan atas tujuan tertentu (Suharsimi, 2010). Kecamatan Sukorejo merupakan salah satu sentra pengasapan ikan tawes di Kabupaten Lamongan.

Jenis data yang digunakan dalam penelitian ini adalah data dengan pendekatan kuantitaf dengan menggunakan analisis nilai tambah metode hayami.

Pengumpulan data menggunakan teknik wawancara, angket, dan pengamatan (Juliansyah, 2011). Teknik pengumpulan data dalam penelitian ini bersumber dari data primer dan data sekunder. Menurut Aziz (2012), data primer adalah data yang diperoleh sendiri oleh perorangan/organisasi langsung melalui objeknya. Sedangkan data sekunder adalah data yang diperoleh dalam bentuk yang sudah jadi berupa publikasi.

Dari data yang dikumpulkan diperoleh beberapa sumber data yang meliputi variabel output, input, dan harga, pendapatan dan keuntungan, serta balas jasa terhadap faktor produksi (Hayami, dkk, 1987; Laila, 2018; Vania, dkk, 2018; Yuniar, dkk, 2019; A; Candra, dkk, 2020). Prosedur perhitungan nilai tambah ada pada Tabel 1 .

Tabel 1.Prosedur Perhitungan Nilai Tambah

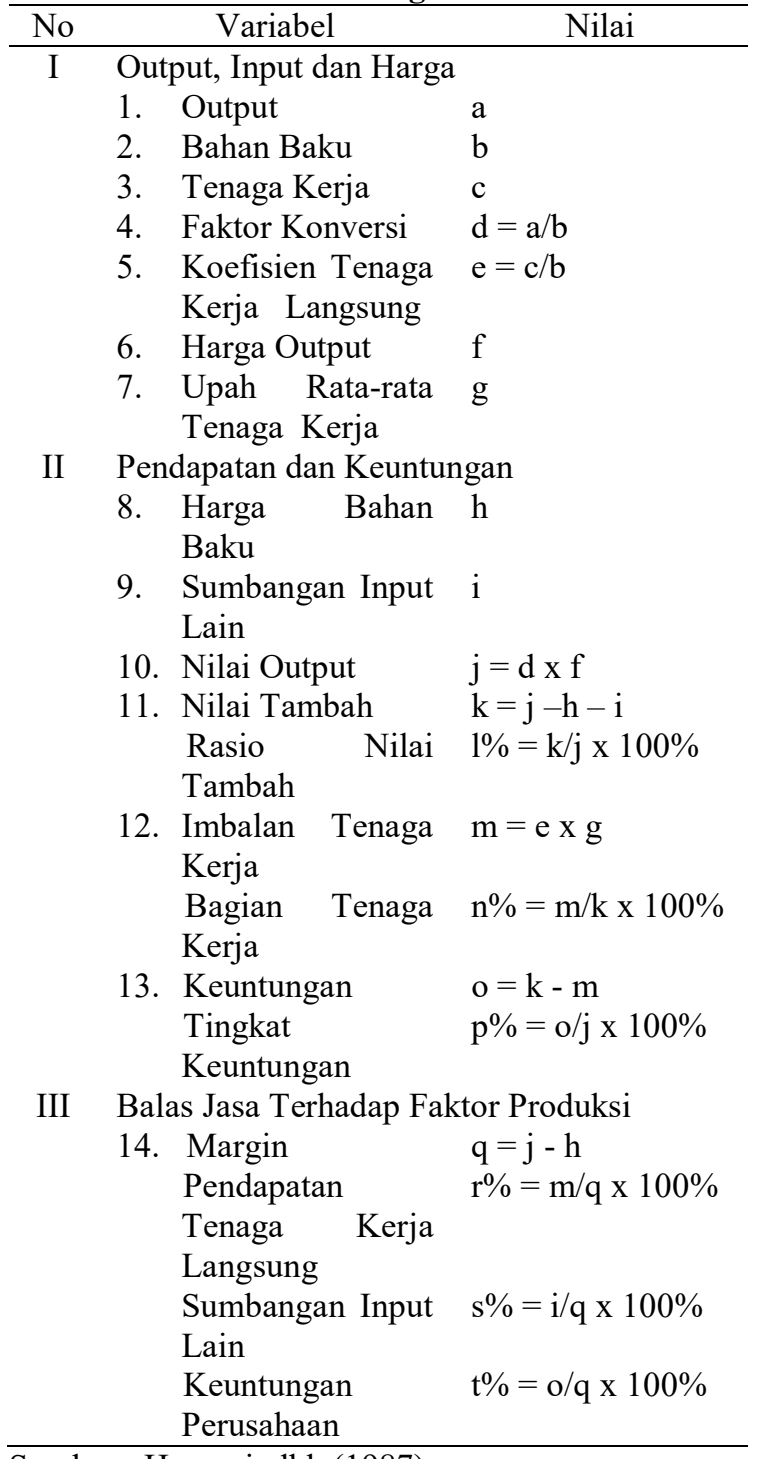

Sumber : Hayami, dkk (1987)

Menurut Febriyanti, dkk (2007), kriteria nilai tambah (NT) adalah:

(1) jika NT $>0$, berarti memberikan nilai tambah (positif).

(2) jika NT $<0$, berarti tidak memberikan nilai tambah (negatif). 
Untuk menganalisis nilai tambah terlebih dahulu harus memiliki data tentang:

(1) kapasitas produksi dari satu unit usaha, jumlah waktu kerja yang digunakan, dan tenaga kerja yang dikerahkan

(2) harga output, upah tenaga kerja, harga bahan baku, dan nilai input lain.

\section{HASIL DAN PEMBAHASAN}

\section{A. Keadaan Umum Daerah}

Sukorejo adalah kelurahan yang berada di wilayah Kecamatan Lamongan, Kabupaten Lamongan. Luas wilayahnya sekitar 204.077 ha, Kelurahan Sukorejo terletak di dataran rendah dan berada pada ketinggian $4 \mathrm{~m}$ dari permukaan laut dengan curah hujan $2.000 \mathrm{~mm} /$ tahun serta suhu rata-rata $34^{\circ} \mathrm{C}$.

Batas-batas wilayahnya adalah sebagai berikut:

Sebelah Utara : Kecamatan Turi

Sebelah Timur : Kelurahan

Tumenggungan

Sebelah Selatan: Kelurahan Sukomulyo Sebelah Barat : Desa Plosowahyu

\section{B. Gambaran Usaha}

Usaha pengawetan ikan asap ini berada di Kelurahan Sukorejo Kecamatan
Lamongan Kabupaten Lamongan. Usaha ini sudah ada sejak tahun 1993. Lokasinya berada di dekat areal sawah tambak, dengan jumlah bangunan sebanyak 17 unit. Masing-masing bangunan dibuat tidak permanen dari bambu dan kayu, dengan ukuran 5 m x 3 $\mathrm{m}$. Status kepemilikan bangunan tersebut adalah sewa.

Lokasi usaha ini sangat strategis karena berdekatan dengan pasar ikan, tempat dimana bahan baku ikan tawes segar diperoleh dan sekaligus sebagai tempat untuk memasarkan hasil ikan tawes asap. Jarak antara lokasi usaha dengan pasar ikan berkisar $150 \mathrm{~m}$.

Jumlah perolehan bahan baku ikan tawes segar sangat dipengaruhi oleh musim, sehingga setiap musim berbedabeda jumlahnya, namun ketersediaannya tetap ada. Adapun ukuran ikan tawes yang digunakan adalah $8-12 / \mathrm{kg}$.

Usaha ini sebagian besar dilakukan oleh perempuan yang berprofesi sebagai ibu rumah tangga yang rumahnya tidak jauh dari lokasi usaha. Usaha ini dilakukan untuk menambah pendapatan rumah tangga, yang rata-rata kepala keluarganya berprofesi sebagai petani dan pembudidaya. 
Waktu kerja dimulai pukul 07.0015.00 WIB, dan dalam setahun terhitung 346 hari kerja.

Hasil pengawetan ikan tawes asap ini tidak hanya dijual di Lamongan namun juga ke Mojokerto. Para pelanggan dari Mojokerto lebih suka ikan tawes asap dari Lamongan dengan alasan karena rasanya enak, tekstur ikannya empuk, dan warna ikannya yang kuning emas kecoklatan.

\section{Konsep Pengawetan Pengasapan Ikan}

Dalam keilmuan pengawetan hasil perikanan bahwasanya pengasapan merupakan bentuk pengawetan produk dengan menggunakan garam, panas, dan asap. Proses penggaraman dan pemanasan membantu menurunkan kadar cairan tubuh ikan, serta berfungsi membunuh bakteri dan mikroorganisme penyebab pembusukan serta membantu meningkatkan jumlah partikel asap yang harus melekat pada tubuh ikan.

Dalam proses pengasapan ikan, unsur yang paling berperan adalah asap yang dihasilkan dari pembakaran kayu. Adapun peran dari unsur ini adalah:

(1) sebagai desinfektan yang menghambat pertumbuhan atau membunuh mikroorganisme penyebab pembusukan yang terdapat dalam tubuh ikan;

(2) sebagai pemberi warna pada tubuh ikan, sehingga ikan yang telah diawetkan dengan proses pengasapan berwarna kuning keemasan dan dapat membangkitkan selera konsumen untuk menikmatinya;

(3) sebagai bahan pengawet, karena unsur-unsur kimia yang terkandung di dalam asap mampu memberikan kekuatan pada tubuh ikan untuk melawan aktivitas penyebab ketengikan (Eddy, dkk, 2009).

Tujuan pengasapan adalah untuk pengawetan dan membentuk sifat organoleptik yang meliputi: (1) cita rasa asap, (2) warna spesifik, dan (3) meningkatkan keempukan daging (Latif, 2014).

Adapun tahapan proses pengasapan ada pada Gambar 1. Proses pengasapan dimulai dari persiapan bahan baku ikan tawes dengan ukurang $8-12 / \mathrm{kg}$, setelah itu dilakukan penyiangan ikan dengan diambil isi perutnya dan insangnya, kemudian dicuci sampai bersih dan ditiriskan, langkah selanjutnya adalah penyusunan ikan di atas tempat pemanggang, setelah itu bisa dilakukan proses pengasapan. Namun sebelum proses dimulai hal penting yang perlu 
diperhatikan adalah penggunaan bahan bakar, dimana akan berpengaruh terhadap cita rasa asap. Bahan bakar yang digunakan adalah tempurung kelapa, dipilihnya bahan tersebut karena aroma asap yang ditimbulkan lebih unggul, dan kaya kandungan aromatiknya.

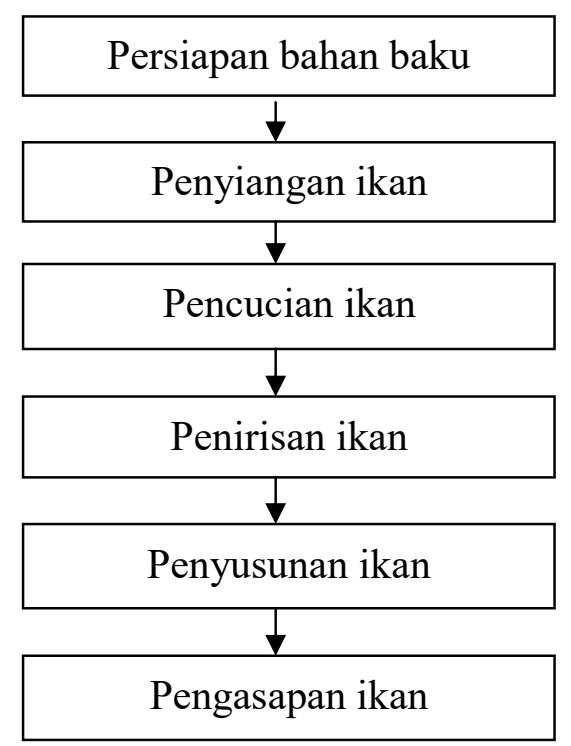

Gambar 1. Tahapan Proses Pengasapan

Setelah proses pengasapan selesai, maka ikan dibiarkan dingin hingga sama dengan suhu ruangan, kemudian ikan siap dipasarkan. Adapun bentuk ikan tawes asap yang siap untuk dipasarkan ada pada gambar 2.

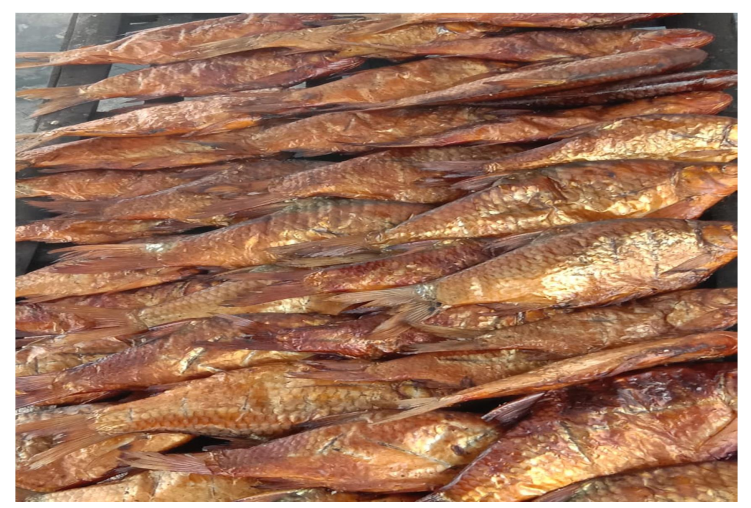

Gambar 2. Ikan Tawes Asap

\section{Analisis Nilai Tambah}

Pengertian nilai tambah adalah pertambahan nilai suatu komoditi karena adanya input fungsional yang diberikan pada komoditi yang bersangkutan. Input fungsional tersebut berupa proses mengubah bentuk (form utility), memindahkan tempat (place utility), maupun menyimpan (time utility) (Hayami, dkk, 1987)..

Dalam proses pengolahan nilai tambah dapat didefinisikan sebagai selisih antara nilai produk dengan nilai biaya bahan baku dan input lainnya, tidak termasuk tenaga kerja.

Analisis nilai tambah melalui metode Hayami ini dapat menghasilkan beberapa informasi penting, yaitu:

(1) perkiraan nilai tambah, dalam rupiah;

(2) rasio nilai tambah terhadap nilai produk jadi, dalam persen;

(3) imbalan jasa tenaga kerja, dalam rupiah;

(4) bagian tenaga kerja, dalam persen;

(5) keuntungan yang diterima perusahaan, dalam rupiah;

(6) tingkat keuntungan perusahaan, dalam persen (Eyverson, dkk, 2012).

Prosedur perhitungan nilai tambah ada pada Tabel 2 . 
Tabel 2. Prosedur Perhitungan Nilai Tambah Per Tahun

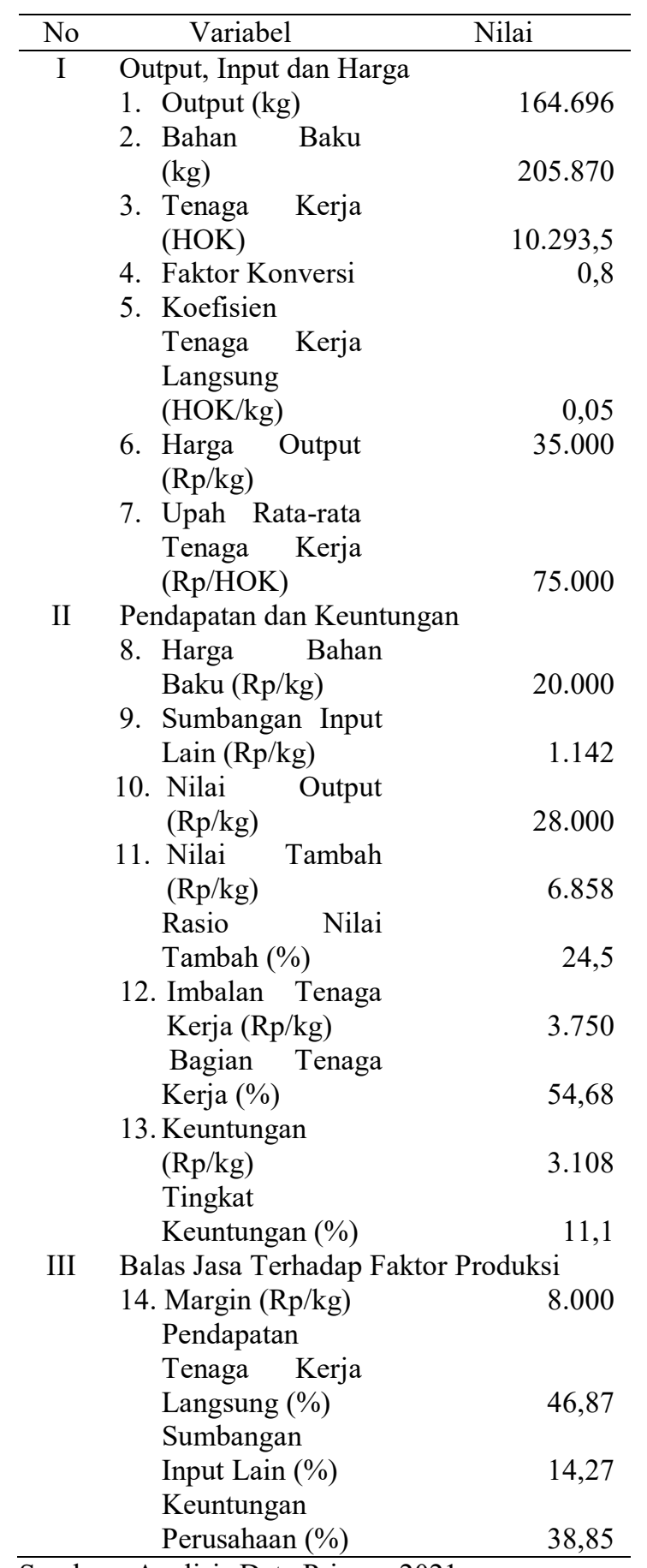

Sumber : Analisis Data Primer, 2021

1. Output

Output dari pengawetan ini adalah ikan tawes asap dengan jumlah 164.696 $\mathrm{kg}$ dalam setahun.
2. Bahan Baku

$$
\text { Dalam proses pengawetan }
$$
dibutuhkan bahan baku ikan tawes segar dengan ukuran $8-12 / \mathrm{kg}$. Dimana dalam setahun terdapat 346 kali produksi sehingga total kebutuhan bahan bakunya adalah $205.870 \mathrm{~kg}$.

\section{Tenaga Kerja}

Terdapat 17 pelaku usaha dalam usaha pengawetan ini dan jumlah tenaga kerjanya adalah 34 orang. Pelaku usaha sekaligus merangkap sebagai tenaga kerja. Tugas dari tenaga kerja tersebut adalah melakukan proses tahapan pengawetan mulai dari persiapan bahan baku hingga ikan asap siap dipasarkan. Adapun perhitungan $\mathrm{HOK}$ nya sebesar 10.293,5.

\section{Faktor Konversi}

Nilai faktor konversinya adalah 0,8 , artinya bahwa setiap $1 \mathrm{~kg}$ bahan baku yang digunakan akan menghasilkan 0,8 kg ikan tawes asap.

\section{Koefisien Tenaga Kerja \\ Nilai koefisien tenaga kerjanya} adalah 0,05 , artinya bahwa setiap $1 \mathrm{~kg}$ bahan baku yang digunakan membutuhkan 0,05 HOK. 


\section{Harga Output}

Harga output dari ikan tawes asap adalah Rp35.000/kg.

\section{Upah Rata-rata Tenaga Kerja}

Besarnya upah rarat-rata tenaga kerja pengawetan ikan tawes asap adalah Rp75.000/HOK.

\section{Harga Bahan Baku}

Harga bahan baku ikan tawes segar yang dibutuhkan dalam setiap kali produksi adalah Rp20.000/kg.

\section{Sumbangan Input Lain}

Dalam produksi pengawetan ikan tawes asap membutuhkan input pendukung berupa tempurung kelapa, dalam setahun kebutuhan input tersebut memerlukan biaya sebesar Rp235.280.000. Biaya tersebut digunakan untuk $205.870 \mathrm{~kg}$ ikan tawes segar yang diolah. Sehingga per kg nya menghabiskan biaya Rp1.142.

\section{Nilai Output}

Nilai outputnya per $\mathrm{kg}$ adalah Rp28.000, merupakan hasil dari perkalian antara faktor konversi dengan harga output.
11. Nilai Tambah dan Rasio Nilai Tambah

Nilai tambah yang diperoleh dari pengawetan ikan tawes asap ini adalah $\mathrm{Rp} 6.858 / \mathrm{kg}$ dengan rasio nilai tambahnya sebesar $24,5 \%$.

12. Imbalan Tenaga Kerja dan Bagian Tenaga Kerja

Imbalan tenaga kerja yang diberikan dari setiap $1 \mathrm{~kg}$ bahan baku yang diolah adalah Rp3.750 dengan prosentase bagian tenaga kerja sebesar $54,68 \%$.

13. Keuntungan dan Tingkat Keuntungan

Keuntungan yang diperoleh dari pengawetan ikan tawes asap adalah Rp3.108/kg dengan tingkat keuntungan sebesar $11,1 \%$.

14. Margin, Pendapatan Tenaga Kerja Langsung, Sumbangan Input Lain, dan Keuntungan Perusahaan

Nilai marginnya sebesar $\mathrm{Rp} 8.000 / \mathrm{kg}$, pendapatan tenaga kerja langsung sebesar 46,87\%, sumbangan input lain sebesar 14,27\%, dan keuntungan perusahaan sebesar 38,85\%. 


\section{KESIMPULAN DAN SARAN}

Dari hasil penelitian yang telah dilakukan, dengan metode hayami diperoleh nilai tambah dari pengawetan ikan tawes asap di Kabupaten Lamongan sebesar Rp6.858/kg dengan rasio nilai tambahnya sebesar $24,5 \%$.

Besarnya nilai tambah sangat dipengaruhi oleh biaya produksi, oleh karena itu diperlukan efisiensi faktor produksi untuk menaikkan nilai tambah.

Disamping itu juga perlu adanya pendampingan dan sosialisasi dari instansi terkait agar bisa meningkatkan nilai tambah.

\section{UCAPAN TERIMA KASIH}

Penelitian ini merupakan penelitian hibah internal yang diperoleh dari Lembaga Penelitian, Pengembangan, dan Pengabdian Masyarakat Universitas Islam Lamongan tahun anggaran 2021. Dimana dalam penyelesaian penelitian ini tidak lepas dari bantuan berbagai pihak. Oleh karena itu kami ingin mengucapkan banyak terima kasih kepada:

(1) Yayasan Pembina Perguruan Tinggi Islam "Sunan Giri” Lamongan.

(2) Universitas Islam Lamongan.

(3) Lembaga Penelitian, Pengembangan, dan Pengabdian Masyarakat Universitas Islam Lamongan.
(4) Berbagai pihak yang telah membantu dalam penyelesaian penelitian ini.

\section{DAFTAR PUSTAKA}

Adawyah, R. (2014). Pengolahan dan Pengawetan Ikan. Jakarta : PT. Bumi Aksara.

Aji, V.A., Yudhistira, R., \& Sutopo, W. (2018). Analisis Nilai Tambah Pengolahan Ikan Lemuru Menggunakan Metode Hayami. Jurnal Ilmiah Teknik Industri. 17(1) : 56-61.

Arikunto, S. (2010). Prosedur Penelitian Suatu Pendekatan Praktik. Rineka Cipta. Jakarta.

Eddy, A., \& Evi, L. (2009). Pengawetan Dan Pengolahan Ikan. Kanisius. Yogyakarta.

F, Rahardi., Regina, K \& Nazaruddin. (2004). Agribisnis Perikanan. Penebar Swadaya. Jakarta.

Febriyanti., Affandi, M.I., \& Kalsum, U. (2017). Analisis Finansial dan Nilai Tambah Agroindustri Keripik Pisang Skala UMK di Kota Metro. Jurnal Ilmu-ilmu Agribisnis, 5(1) : 48-56.

Firdaus, M, A. (2012). Metode Penelitian. Jelajah Nusa. Tangerang.

Hayami, Y., Kawagoe, T., Morooka, Y., \& Siregar, M. (1987). Agricultural Marketing and Processing in Upland Java A Perpective from a Sunda Village. Bogor : CPGRT Centre.

Intyas, C. A., Firdaus, M., \& Aziz, A. (2020). Analisis Nilai Tambah Ikan Layur (Trichiurus savala) Kering di UKM Mawardi Desa Weru, Kecamatan Paciran Kabupaten Lamongan. Prosiding Simposium Nasional VII Kelautan dan Perikanan Fakultas Ilmu Kelautan 
dan Perikanan Universitas Hasanuddin, Makasar. pp. 181-185.

Muharom. Y.P., Anna. Z., Riyantini. I., \& Suryana. A.A.H. (2019). Analisis Nilai Tambah Industri Pengolahan Ikan Tuna di Kawasan Pelabuhan Perikanan Samudera (PPS) Nizam Zachman Jakarta. Jurnal Perikanan dan Kelautan. Fakultas Ilmu Perikanan dan Kelautan Universitas Padjadjaran. 10(1) : 9-16

Noor, J. (2011). Metodologi penelitian Skripsi, Tesis, Disertasi dan Karya Ilmiah. Kharisma Putra Utama. Jakarta.
Nuzuliyah. L. (2018). Analisis Nilai Tabah Produk Olahan Tanaman Rimpang. Jurnal Teknologi dan Manajemen Agroindustri, 7(1) : 3137.

Ruauw, E. (2012). Analisis Keuntungan dan Nilai Tambah Agroindustri Manisan Pala di UD Putri di Kota Bitung. Jurnal Agri Sosio Ekonomi, $8(1): 31-43$

S, Wibowo. (2002). Industri Pengasapan Ikan. Penebar Swadaya. Jakarta.

Sahubawa, L \& Ustadi. (2014). Teknologi Pengawetan dan Pengolahan Hasil Perikanan. Bulaksumur, Yogyakarta : Gadjah Mada Press. 